\title{
Governance of Environment-Enhancing Technical change - past experiences and suggestions for improvement ${ }^{1}$
}

\author{
MERIT Research Memorandum 20-013 \\ March, 2000
}

\author{
René KEMP \\ MERIT \\ Maastricht University \\ P.O. Box 616 \\ NL-6200 MD Maastricht \\ r.kemp@merit.unimaas.nl
}

\begin{abstract}
There is much talk about environmental policies being faulty. Past policies are being criticised for failing to achieve environmental goals (the environmentalist complaint), for being overly expensive (the industrialist complaint) and for failing to encourage innovation and dynamic efficiency (the complaint of economists dealing with innovation). This paper looks at the innovation and technology adoption effects of past environmental policies. It finds indeed few examples of environmental policies that stimulated innovation. The common technology response is the use of expensive end-of-pipe solutions and incremental process changes offering limited environmental gains. This begs the question: why did the policies fail to promote more radical innovation and dynamic efficiency? One explanation-well-recognised in the economic literature-is the capture of government policies by special interests. This paper offers a second explanation-based on innovation and technology adoption studieswhich says that in order to have a decisive and socially beneficial influence policy instruments must be fine-tuned to the circumstances in which sociotechnical change processes occur and tip the balance. Within this alternative view, the starting point of government interventions is the capabilities, interests, interdependencies and games of social actors around an environmental problem instead of the set of environmental policy instruments for achieving an environmental goal. The paper sees a need for government authorities to be explicitly concerned with technical change (rather than implicitly through a change in the economic frame conditions) and to be concerned with institutional arrangements beyond the choice of policy instruments, and act as a change agent. This requires different roles for policy makers: that of a sponsor, planner, regulator, matchmaker, alignment actor and 'creative game regulator'. The paper offers two perspectives on environmental policy: an instrument one and a modulation one. The latter is especially important for promoting innovation and bringing about radical change, something which is very difficult with traditional regulatory instruments. Instruments for promoting environment-enhancing technical change are appraised and suggestions are offered for the purposes for which different policy instruments may be used in differing economic contexts.
\end{abstract}

\footnotetext{
${ }^{1}$ This research memorandum is written in the context of the PRET project supported by the Netherlands Organisation for Scientific Research (NWO). It draws on earlier work done by the author on environmental policy instruments and environmental innovation, described in his book Environmental Policy and Technical Change. The author wants to thank Aart de Zeeuw, Frank den Butter, Peter Mulder and other participants of a PRET workshop for comments on an earlier version of the paper.
} 


\section{Technology impacts of environmental policies}

There exists a small literature on the impact of actual environmental regulations on compliance innovation and clean technology. This literature consists of the work of Ashford and Heaton in the 1980s in the US, Kemp (1997) and a number of German studies (Hartje (1985); Hemmelskamp, 1998; Elder (1999)). The focus of these studies is on technical innovation. What these studies show is that the technology responses range from the diffusion of existing technology, incremental changes in processes, product reformulation to product substitution and the development of new processes. The most common responses to regulation are incremental innovation in processes and products and diffusion of existing technology (in the form of end-of-pipe solutions and non-innovative substitutions of existing substances). Often the new technologies are developed by firms outside the regulated industry, which means that in the past industry was reliant upon suppliers, capital good suppliers and environmental technology suppliers. (This is changing with the growing attention in environmental policy and industry to prevention and product change). The studies also show, unsurprisingly, that the stringency of the regulation is an important determinant of the degree of innovation with stringent regulations such as product bans being necessary for radical technology responses. Technology-forcing standards appear to be a necessary condition for bringing about innovative compliance responses. The studies further show that long before the regulations are promulgated there is a search process for solutions to the problem, both by the regulated industry (mostly for defensive reasons), their suppliers and outsiders. This happened in the case of PCBs and CFCs where firms both in and outside the chemical industry were looking for substitutes 10 year before the use of PCBs and CFCs was banned (Ashford, et al., 1985). Of course, the certainty that their product or activity would be subject to regulations was an important factor.

As to the nature (incremental or radical, product or process related) and the source of technological solutions an internal OECD report established that:

- High volume, mature sectors were resistant to change, although very amenable to environmental monitoring and process controls that improved efficiency. This fits with the Abernathy-Utterback product life cycle model that during the life time of a product a sector becomes rigid, especially those sectors that are capital intensive. An alternative explanation is that such sectors are powerful and able to fight off regulations that require a major change in their process technologies.

- Significant process innovations occurred in response to stringent regulations that gave firms in the regulated industry enough time to develop comprehensive strategies. There is a tradeoff between achieving quick results and radical change.

- Smaller firms and potential new entrants tended to develop more innovative responses. A possible explanation for this is that incumbent firms, especially the big ones, are vested in old technologies both economically and mentally.

- The environmental goods and services industry provided compliance strategies that were at best incrementally innovative, but which diffused fast, due to their lack of disruption and acceptability to regulators.

- Regulatory flexibility toward the means of compliance, variation in the requirements imposed on different sectors, and compliance time periods were 
aspects of performance standards that contributed to the development of superior technological responses.

What the studies show is that technology responses are not a simple response to a regulatory pressure. Apart from the regulatory stimulus, there were many other factors that exercised influence. This suggests that the stimulus-response model is too simple. For one thing it assumes that social innovation starts with regulation which is most often not the case. Regulation is not the be-all and end-all of social innovation. The knowledge for such innovations is usually available, regulations may provide the leverage or some extra stimulus for the exploitation. Regulation is but one of many stimuli. It may in fact not be needed for environmental innovation. Many technologies producing environmental benefits are adopted for normal business reasons of reducing costs and enhancing product quality. These options are referred to as eco-efficiency options. ${ }^{2}$ But even for environmentally beneficial technologies that do not combine environmental gains with economic gains regulation may not be needed. In the case of an environmentally harmful product there will always will be pressures to reduce the harm. These pressures come from a range of actors: insurance companies, banks, customers, employees, environmentalist groups, and consumer organisations through product tests which include environmental aspects. ${ }^{3}$

These pressures act as stimuli for technology development and can be seen as diffuse technology forcing. People want firms not only to deliver goods and services but also to behave in a socially responsible way. The public/political climate generates a credibility pressure on firms: they lose goodwill if they neglect environmental issues too openly. When the early synthetic detergents of the 1960s created very visible environmental problems (foam in surface water), the detergent companies and especially their suppliers developed new processes leading to biodegradable synthetic detergents, without government regulation (although with the expectation that there might be regulation in the future). The voicing of concern and the threat of regulation may be enough to induce industry to look for alternative. Given the information problem of the government, the threat of regulation may be a better means to stimulate technological innovation than actual regulations (Rip and Kemp, 1998).

A real problem for regulators is that environmental innovations and technologies not only must be environmentally beneficial but also must meet a range of other demands: they should be expendable, it should be possible to fit them into existing processes, and in the case of products, they should meet user requirements in terms of performance characteristics. Water saving shower heads should be comfortable (have sufficient stream power) and environmentally improved detergents should have good washing performance. User benefits and social performance benefits must be balanced and cooptimised. It is this co-optimisation that creates a problem for innovators and for environmental regulators. For example, it proved to be very difficult to develop phosphate free detergents with equal washing power as the phosphate-based. It took

\footnotetext{
2 The term eco-efficiency is coined by the World Business Council for Sustainable Development. See Schmidtheiny (1996).

${ }^{3}$ According to Baynes an environmental progamme manager of Sony the score of consumer products in consumer organisation product tests is determined for about $20 \%$ by environmental aspects.
} 
German companies many years and more than 500 mln DM to develop alternatives with satisfactory washing performance. The actual regulations on phosphate content coevolved with the results from product tests (both toxicological tests and tests about washing performance) (Hartje, 1985).

What this example shows is that innovations can not simply be 'elicited by legal fiat' (Heaton, 1990), moulded in a pre-defined, socially desirable shape. This is why emission limits are based on assessments what is technologically possible and economically affordable, and why environmental permits are often based on the concept of Best Available Technology or Best Practicable Means that are specified in BAT lists or guidance notes for permitting agents. There is a dynamic interplay between innovation and regulation; the stimulus response model fails to appreciate this. (In fact, innovation, in the sense of a available technological solution to problem, may pave the way and thus be the stimulus for regulation, which suggests that the causality goes either way).

The obvious implication of all this is that the governance of technical change is not a simple matter. It is difficult to design instruments that 'do the job', and do it well: that lead to Pareto-efficient outcomes in the sense that society as a whole is better off. Evaluation studies of environmental policy instruments show that the instruments in themselves are either ineffective in achieving a set goal or outcome, or inefficient in terms of costs or technology choice. An example is the ONO technology used in the Dutch metal plating industry to control the release of metals into receiving waters which led to production of toxic sludge containing heavy metals which had to be treated. ${ }^{4}$

Below we will provide a discussion of experiences with various environmental policies, especially subsidies and covenants. Starting with subsidies. Subsidies are an important element of government policy towards technology. They are a key instrument of innovation policy. As a politically attractive instrument, they have been an important part of environmental policies. In the Netherlands, several studies have been undertaken into the effectiveness of investment subsidies for environmental technologies. A common outcomes of such studies is that subsidies had a limited impact on decisions. This was true for investment subsidies under the "Wet Investeringsregeling" (WIR) which found that investment subsidies for environmental technologies (being 15 per cent of total investment costs) induced only 8 per cent of the firms to undertake investments they would not have done otherwise (Tweede Kamer, 1987, p.39). Curiously, this led the Dutch government to conclude that the subsidy scheme was 'reasonably effective'. The same result is found a study of Vermeulen (1992 which analysed the effectiveness of three types of investment subsidies. The results of this study, based on a questionnaire (just like the study of the WIR), are given in Table 1.

\footnotetext{
${ }^{4}$ A discussion of the factors that led to the use of ONO installations for the control of metal discharges is offered in Kemp (1997).
} 
Table 1.The (non)effectiveness of investment subsidies for environmental technologies

\begin{tabular}{lccc}
\hline & PCBs $^{*}$ & $\begin{array}{l}\text { Silent } \\
\text { trucks }\end{array}$ & \multicolumn{2}{l}{$\begin{array}{l}\text { Manure } \\
\text { storage }\end{array}$} \\
\hline very effective & $0 \%$ & $2 \%$ & $1 \%$ \\
reasonably effective & $37 \%$ & $22 \%$ & $20 \%$ \\
hardly effective & $13 \%$ & $23 \%$ & $3 \%$ \\
not effective & $50 \%$ & $52 \%$ & $76 \%$ \\
\hline
\end{tabular}

Note: * Polychlorinated Biphenyls

Source: Vermeulen (1992, p.210)

According to the study by Vermeulen, the investment subsidies for the replacement of PCB equipment, quieter new trucks, and the storage of manure were effective in only a small number of cases. The subsidies were the primary reason for investing in the environmentally beneficial technologies in 2 per cent of the cases for silent trucks and 1 per cent for manure storage. For PCB replacement equipment the figure was even zero. The investment subsidies were reasonably effective for 37 per cent of the firms that used PCBs (and only in 22 and 20 per cent of the cases in the other two sectors). In all three cases, other factors were more important than the subsidies, such as fuel economy, road performance and comfort in the case of silent trucks, health and safety considerations in the case of PCB replacement, and environmental regulations in the case of the manure storage. ${ }^{5}$ According to Vermeulen, under the three programmes, 200 million guilders (about 125 million US dollars) were spent without having any effect on polluter's purchasing decisions.

I myself studied the effectiveness of investment subsidies for thermal insulation under the National Insulation Programme (NIP) in the Netherlands. I used econometric analysis for this in the form of diffusion models that were fitted to the data. The statistical analysis established that there was only a weak positive relationship between the subsidies for thermal home improvements which totalled 2 billion Dutch guilders $(0.9$ billion dollar at the current exchange rate) and the diffusion of thermal insulation technologies: the coefficients of the dummy variables for investment subsidies were positive but not significantly different from zero at the 5 per cent significance level. This result is confirmed by another study which asked applicants for the subsidy about their motivation for investing in thermal home insulation. Only 11 per cent of the respondents said that the subsidy was the primary motivation for investing in thermal insulation (Beumer et al., 1993, p.42). Cost savings and improved comfort were the main reasons for investing in thermal home insulation.

\footnotetext{
5 Vermeulen also analysed whether the information provided by government authorities about the availability of subsidies and about the adverse environmental effects of existing technologies and practices influenced the decisions of firms to invest in environmentally preferable technologies. This was only so for PCBs, which not only had adverse health and detrimental environmental effects but also posed a fire and security risk for PCB-using firms.
} 
Other evaluation studies of investment subsidies for environmentally beneficial technologies (including energy conservation, solar boilers and co-generation of heat and power) arrive at similar conclusions. With the exception of the investment subsidy for CHP, and, possibly, the subsidy for wind turbines, the effectiveness of the investment subsidies in the Netherlands was small (Evaluatiecommissie WABM, 1992).

In all the examples above, the subsidies provided applicants with a windfall gain. It is unclear to what extent they encouraged technological innovation, but given that the subsidies hardly influenced adopter decisions, the innovation effects are likely to be small. This does not disqualify investment subsidies as such. There are also examples of subsidy schemes that were effective. An example is the subsidy for clean automobiles combined with a tax for cars with high emission levels introduced in the Netherlands in 1986 to stimulate clean vehicles. The way in which the system worked was that the subsidies for clean cars (equipped with a catalytic converter) were paid out of the extra tax revenues from the sales of highly polluting cars. This policy proved to be very effective: the share of clean cars in new car sales increased from 15 per cent in 1986 to 90 per cent in $1990 .^{6}$ The same kind of policy was used to encourage the supply and distribution of unleaded gasoline to protect catalytic converter emission control systems used in cars. Due to a differentiation in excise taxes, unleaded gasoline (first only regular but later also super gasoline) became cheaper than leaded gasoline. Oil companies quickly responded to these changes in the tax regime by offering unleaded gasoline for sale. ${ }^{7}$

What about the effectiveness of subsidies for the development of environmentally preferable technologies? Did R\&D subsidies stimulate firms to undertake research in environmental technology, that is, research they would not have done otherwise? This is a question which has not been studied in a systematic way, at least not in the Netherlands. However, the evidence that is available suggests that R\&D subsidies in the Netherlands for environmental technology have been of limited effectiveness. According to the study by Olsthoorn, Oosterhuis and Verbruggen (1992, p.18), the "Stimuleringsregeling Milieutechnologie" (STIR-MT) for the development of environmental technology did not elicit new research projects. This conclusion corresponds with the observation by de Jong and van der Ven (1985, pp.78-79) that innovator firms develop environmentally beneficial technologies not because a subsidy is available but because they believe a market exists for the new technology. The conclusion is at odds with two other evaluation studies, quoted in Cramer et al. (1990), that find that of the 10 projects that received financial support under the Clean Technology programme in the Netherlands, five would never have been initiated. However, it turned out that many of the projects funded under the programme were second-rate projects: of the ten projects only seven were technically successful and only four of them were applied in practice. On the whole the results are not encouraging: it may be that the R\&D subsidies accelerated the

\footnotetext{
${ }^{6}$ Evaluatiecommissie WABM (1992, p.39) based on Klok (1989b).

${ }^{7}$ The quick response of oil companies was due in part to the fact that the manufacture of unleaded gasoline did not require any technological innovation. The manufacture of (high-performance) unleaded gasoline was something oil companies in the US had already mastered in the 1970s, to comply with US environmental regulations (Ashford et al., 1985, pp.435-436).
} 
development of environmental technologies, but this is unclear. There are few examples of successful clean technologies requiring a technology development programme.

The experience with the Danish Clean Technology Development Programme, described in Georg et al. (1992) is more positive. Under the programme, industries, private and semi-governmental research institutions could apply for financial aid for developing and implementing clean technology. The programme was oriented at stimulating preventive process solutions and cooperation among technology suppliers, research institutes, consultancy firms, and users. The Danish Environmental Protection Agency played an active role in selecting environmentally beneficial projects and in finding the right partner with whom to co-operate. That is, the agency acted as a match maker to elicit environmentally innovative solutions, something that previous subsidy programmes had failed to do. ${ }^{8}$ According to the authors, the Danish programme was a success. In almost all cases, appropriate technical solutions were found for the environment problems at hand. In more than half of the projects, substantial environmental improvements were achieved at low costs. Some projects led to net economic gains for the polluting firms.

\section{Taxes and tradeable permits}

What about the experiences with taxes and tradeable permits? Did they promote innovation? The answer is that we do not know. The experiences with the tradeable permits for $\mathrm{SO} 2$ are very positive as far as efficiency is concerned. In a first estimation, cost gains of 50\% have been reported (Palmer et al., 1995) But there is little evidence that they promoted innovation. The innovation effects of environmental taxes is a topic which has been barely analysed. But as the taxes are usually set at a low level, I expect the innovation effects to be very low.

\section{Covenants}

What are the experiences with covenants (environmental agreements between industry and government) in promoting innovation and environmental technology diffusion? Covenants are negotiated agreements between industry and the government in which the industry promises to reduce the environmental burden of their products and activities. They are a relatively new instrument of environmental policy. The effectiveness of eight product-related covenants in the Netherlands is analysed in Klok (1989a). The covenants covered products such as mercury-oxide batteries, alkaline batteries, beverage packages, heavy trucks, and PET bottles and the use of cadmium in beer cases, CFCs in aerosols, and phosphates in detergents. Most covenants were about the substitution of an environmentally hazardous substance. According to Klok, the effectiveness of covenants was typically small: when environmental improvements were achieved, this was more due to autonomous technological change, external regulations (such as EC guidelines), and the evolution of market demand than to covenants. Furthermore, there is little evidence that the covenants fostered technological innovation. An exception is the KWS2000 programme in the Netherlands to reduce VOC emissions which stimulated research into low-solvent paints, especially for the housing market. Covenants are used now for

\footnotetext{
${ }^{8}$ The project was more than a subsidy programme. The programme brought together firms with an environmental problem and firms and institutes that could provides solutions to these problems.
} 
achieving reductions in energy use in the Netherlands (but also Germany), where sectors promised to reduce their energy use by 20 per cent in 2000 compared to 1989 levels. Again, the impact on innovation is likely to be limited as such reductions can be met with existing technology. In our view, this demonstrates a disadvantage of covenants, and, more general, of public-private partnerships. If policy makers want to make further use of covenants, these should be more oriented towards innovation.

\section{Innovation waivers}

One way to promote environmental innovation is through the use of innovation wavers. Innovation waivers are incentive devices built into environmental regulation. Generally, they extend the deadline by which industry must install pollution control equipment to meet emission limitation requirements. They exempt industry from penalties during trial periods and offer the prospect of cost savings derived from superior technology (Ashford et al., 1985, p.444). In theory, innovation waivers seem very attractive for both potential innovators and the regulating agency. They have been used in the US with little success. The reasons for this had to do with the short and inflexible deadlines which acted as a disincentive for innovation, especially for radical innovation, and shortfalls in the way in which the programme was administered. Under the Clean Air Act, the responsibility of issuing innovation waivers was given to the Stationary Source Compliance Division (SSCD) of the Environmental Protection Agency, a division with limited technical expertise, whose primary task was enforcement. As it turned out, the SSCD narrowly interpreted the waiver provisions, provided little guidance and the agency took a long time before it arrived at a decision.

In retrospect, it is easy to comprehend why innovation waivers were unsuccessful in the above case. This does not disqualify innovation waivers per se. There are several remedies to the problems encountered, many of which are given by the authors - such as administration of the programme by people trained to interact with industry, the establishment of a technology review panel, delineation of eligibility criteria, and longer time allowances. It does illustrate, however, the difficulties in designing regulations that encourage technological change towards efficient conservation of environmental qualities.

After describing the experience with government policies to stimulate environmental benign technologies, I now turn to the topic of best policies to promote the development of environmental innovation and diffusion. There are 2 ways to approach this issue. One way is to focus on policy instruments, and examine for what purposes (stimulation of innovation or diffusion or both) in what technological and economic context they might be usefully applied. This is what I have done in my book Environmental Policy and Technical Change. Another way to tackle the issue, is to take the dynamics of sociotechnical change (including processes of assessment and anticipation) as the starting point for a discussion of governance: how these may be modulated into more environmentally benign directions. The second approach is something that I have explored with Arie Rip in the book chapter Technological Change of Human Choice and Climate Change and two Dutch projects I am presently involved in: the MATRIC and PRET project. It uses a evolutionary view described in Dosi et al (1988), Nelson (1994) Freeman (1992), Edquist (1997), Lipsey (1998), Metcalfe and Georghiou (1998) and Kemp et al. (1998 and 1999) and Faucheux (2000). 


\section{The pros and cons of environmental policy instruments}

This section takes an instrument-based view towards environmental policy. It addresses the question: what is the best environmental policy instrument to encourage technological innovation and diffusion? As I will argue below, there is no single best policy instrument to stimulate clean technology, all instruments have a role to play, depending on the context in which they are to be used. Suggestions are offered as to the purposes for which and context in which particular instruments may be used to obtain environmental protection benefits through the use of technology.

\section{Environmental standards}

As explained in the previous section, the experiences with environmental policies are mixed, and often negative. Emission standards that were often based on available end-ofpipe technologies (which was often the case) provided little incentive for the development of new, more effective technologies; they merely stimulated the diffusion of existing technologies. This demonstrates the danger of using technology-based standards and the importance of taking a long-term view towards environmental protection.

Technology-forcing standards that require the development of new technologies are a better way of encouraging technological innovation, as the regulatory experiences in the United States demonstrate. However, they may impose high costs on industry-unless the regulator is willing to soften and delay standards, but this would have a negative effect on the willingness of suppliers to develop innovations. In our view, technologyforcing standards should only be used when technological opportunities are available that can be developed at low enough costs. The chance that these opportunities will be developed is greater when potential suppliers are located outside the regulated industry. Outsiders are also more likely to develop radical solutions to environmental problems (Heaton, 1990). The reason why innovative solutions are often developed by outsiders is that they have technological capabilities for dealing with environmental problems that the regulated industry lacks, they also have a stronger interest in developing compliance technology.

When using standards it is important that the regulator gives industry enough time to develop solutions that are environmentally benign and meet important user requirements. Time may also be needed for finding out whether a solution is environmentally benign and does not pose other hazards. One way of dealing with the problem of compliance time is by giving firms innovation waivers that exempt them from regulations during a certain period. If innovation waivers are used, it is important that firms are given sufficiently long time allowances and that the eligibility criteria are clear. Another strategy is the setting of long-term standards that require the development of new technology. To deal with the problem of strategic behaviour of industry, such standards are best supplemented by a system of fines. Fines also make the system more flexible and offer a way out of the economic problem of compliance for firms with relatively high compliance costs. 


\section{Economic incentives}

Decentralized incentive systems (such as taxes and tradeable pollution rights) are an alternative to command-and-control policies. They are favoured by economists and international organizations such as the OECD. The theoretical benefits of incentive-based approaches to reducing pollutant emissions are many. First, effluent fees (or charges and taxes) and tradeable quotas are more efficient because every polluter is given the choice between compliance and paying the polluter's bill. The polluting firm cannot be forced to undertake emissions control of which the marginal costs are higher than the effluent fee. This means that environmental benefits are achieved at the lowest abatement costs. Second, there is a financial incentive to diminish all pollution-not merely up to the level of emissions standards. They create a constant demand for innovation (Stewart, 1981, p.1373). (The economic belief that incentive-based approaches provide a greater inducement to innovate is based on this argument.) Third, such a system depends less than standards-based policies on the availability of pollution control technology and can therefore be introduced more quickly at lower decisional costs by reducing demands on regulatory process to decide complex, detailed engineering and economic questions (Stewart, 1981, p.1374). Fourth, the danger that polluting industries fail to develop new technologies for strategic reasons is less under an incentive-based regime. And fifth, economic instruments tend to stimulate process-integrated solutions (including recycling technology) rather than end-of-pipe technologies that have been overwhelmingly applied in the past.

A disadvantage of effluent charges is the uncertainty about the polluters' responses. Another disadvantage is that the total environmental costs (abatement costs plus tax payments) are likely to be high, which lowers their political attractiveness, and may induce the regulator to set a low tax (as happened in countries in which they are used). Since freely distributed tradeable pollution quotas do not suffer from this they may be better instruments to stimulate environmental innovation than taxes or charges.

There are other disadvantages of economic instruments. First, in order to be effective, polluters must be responsive to price signals, which is not always the case. For instance, two evaluation studies in the Netherlands revealed that price considerations played a limited role in the timing of investments in thermal home improvements. This suggests that price incentives are probably better suited to change the behaviour of firms than the purchasing decisions of consumers. Second, the price incentive must be sufficiently high to induce firms to develop and implement environmentally beneficial technologies. This was not the case in most environmental policies in which economic instruments were used (an exception is the effluent charge in the Netherlands discussed later on). And third, in dealing with transnational environmental problems such as greenhouse warming, taxes should be used unilaterally only if their introduction does not put national industries at a serious competitive disadvantage - that is, they should be introduced in those sectors where the environmental costs are a small part of total costs or in sectors sheltered from international competition.

\footnotetext{
${ }^{9}$ According to Hahn and Hester (1989, pp.100-101), the US emission trading programme introduced in 1974 resulted in cost savings in emission control between 1 and 13 billion dollars. Almost all of these savings resulted from internal trading.
} 


\section{Subsidies}

Uncertainty about the demand for cleaner technologies, partly related to unpredictable government policy, may call for the use of $R \& D$ subsidies or loans. The agency responsible for the subsidy programme should be careful however not to stimulate second-rate technologies. The use of subsidies should be restricted to environmentally beneficial technologies for which a market does not yet exist, for example, technologies with long development times (as in the case of energy technologies) or technologies for which there are problems of appropriating the benefits of innovation by the innovator (for example, when imitation is easy). $\mathrm{R} \& \mathrm{D}$ programmes may also be used to increase the number of technological solutions when there is uncertainty about environmental solutions. Subsidies for investments in pollution control technology are less useful in our view. They clash with the polluter-pays-principle and are expensive; in addition, evaluation research in the Netherlands has proved them to be only minimally effective. There is a great risk that such subsidies provide windfall gains for the firms and consumers receiving them. They should be used only when a switch to cleaner technology entails high costs and produces competitive disadvantages due to less strict regulation in other countries.

\section{Communication}

Communication instruments can be useful policy tools for addressing information problems related to products and processes. Environmental management and auditing systems in business (required in the Netherlands for large firms), demonstration projects and information campaigns can be useful to ensure that firms make better use of the possibilities available for emission reduction, especially cost-reducing environmental measures. Information disclosure requirements, such as those in the US, that force firms to communicate environment-related information, product information and 'green' labels are also believed to be useful. They increase pressures on firms to improve their environmental record, enhance the environmental awareness of firms, and make the market for green products more transparent. They are useful as additional instruments, not as substitutes for environmental regulations or taxes.

\section{Covenants}

Covenants are a new policy instrument within environmental policy, in Europe and the US. Covenants are contracts between industry or an industrial sector and government in which industry promises to progressively reduce the environmental burden of its activities within a certain period (often five to ten years) according to certain targets. They are also referred to as 'voluntary agreements' as firms that belong to a sector are free to enter the sectoral agreement. (If they don't they will be subject to regular licensing procedures.) Covenants are attractive to industry as they leave industry more freedom with regard to the method and moment of compliance, thus lowering the so-called regulatory burden. By handing over responsibility for achieving environmental improvements to industry, covenants may stimulate environmental responsibility of firms which is important for the wider integration of environmental concerns in companies' decisions. From the viewpoint of the environmental control agency, covenants are 
attractive by lowering the administrative burden and for establishing a better, more cooperative relationship with business.

A clear disadvantage of the use of covenants is the danger of strategic exploitation of the agreements by industrial firms who may engage in free-rider behaviour, or, more likely, underexploit the opportunities for innovation by claiming that it is impossible to meet the targets through compliance technology that meets important user requirements. Such behaviour may jeopardize the fulfillment of environmental agreements. The softness of covenants, or voluntary agreements in general, means that there is little incentive for third-party suppliers to develop compliance technologies as the market for the new technologies is insufficiently secured. If covenants remain to be used in the future, as they probably will be, they should be more oriented towards innovation. One way of doing this is through technology compacts between public authorities and private firms to implement long-term technological change (Banks and Heaton, 1995, p.49). In the compact, industry commits itself to performance goals that require new and advanced technology in exchange for enforcement flexibility and guaranteed acceptance of a new technology. The system looks attractive but, just as covenants, could be exploited by industry who has superior knowledge of what is technologically possible. ${ }^{10}$

This brings us to a more fundamental issue: the ability of the industry to influence and capture the details of environmental policies. Industry is known to have a great influence over the details of environmental policies, especially standards. Thus, an additional criterion on which to judge environmental policy instruments is the chance of institutional capture of policies by special interests.

\section{What role for what instruments?}

A summary of my views on the use of environmental policy instruments is given in Table 2 in the Appendix. The table describes the effectiveness and efficiency characteristics of different policy instruments, the purpose for which they may be used (to stimulate technological innovation or diffusion), and the context in which they may be applied, based on the experiences with environmental policies and studies of environmentally benign technical change. It should be noted that they reflect the views of the author, they are not the outcome of a rigorous model.

\section{Economic incentives}

Economic incentives have an important role to play in environmental policy. They leave freedom as to the choice and moment of compliance, and provide an incentive to go beyond environmental standards. Especially in the case of heterogeneous firms with different production technologies, economic instruments are attractive. They are more economically efficient than standards, giving equivalent environmental improvements at lower costs, which, in principle, allows policy makers to achieve greater emissions reductions. But there are certain limitations to their effective use, which are often not recognised in the discussion on the design of environmental policy. For example, there is

\footnotetext{
${ }^{10}$ Aggeri (1999) offers a discussion of the usefulness of cooperative approaches to promote innovation. He offers useful suggestions how the process of collective learning may be managed.
} 
a danger that economic incentives such as taxes and subsidies provide a too weak and indirect stimulus. Many people who studied the technology responses to environmental pressures take this view. In their study of clean technology in the UK, Irwin and Hooper (1992) found that state incentives had only a marginal impact on innovation. This and other considerations led them to the view that "a sensitive but firm policy of putting regulatory pressure on waste and pollution output will be more effective in focusing industrial minds". Hartje (1984) in studying the innovation decisions of detergent manufacturers doubted that a tax policy would have achieved a switch away from phosphate-based detergents. The 50 per cent reduction requirement for phosphates created a certain market of significant size for phosphate substitutes.

The idea that regulations are more effective and better suited for making firms invest in environmental measures is also widely shared by environmental authorities. For example, in the US, environmental authorities responsible for pollution prevention programmes stated almost without exception that stringent and certain regulatory demands (such as emission, effluent, or exposure standards, or product bans and phase-outs) are necessary to effectuate pollution prevention. Economic instruments are seen as complements to, not substitutes for, regulatory requirements (Ashford, 1993, p.296).

In general, economic incentives may be more suited to stimulate technological diffusion than innovation. A clear example of the effectiveness of economic instruments is provided by the diffusion of biological waste-water treatment plants in the Netherlands. The increase in the effluent charge from Dfl 5.42 in 1973 to Dfl 74.26 in 1991 per unit of 'population equivalent' (the typical measuring rod) induced many firms to invest to invest in biological effluent treatment systems. The diffusion speed was considerably higher for indirect dischargers who discharged their effluent into a collective effluent treatment plant than for direct dischargers. A counter example also from the Netherlands is the diffusion of thermal home improvement technologies where subsidies and energy prices played a limited role in the timing of thermal home improvements.

\section{R\&D progammes}

In order to stimulate technological innovation, a more focused approach may be needed. One way of doing this is through $R \& D$ programmes for environmental technologies or more environmentally benign energy technologies. But as noted with R\&D support there is always the danger that the programmes promote second-rate technologies and provide windfall gains to the recipients.

\section{Technology-forcing standards}

Another strategy to promote environmental innovation is by specifying strict environmental standards that require the development of new technologies. However, this should be done only in situations where the environmental risks are large and acute and when there is consensus about the most viable technological solution or trajectory. If there is no such consensus there is a danger that technology-forcing standards lock industry into overly expensive and suboptimal technical solutions. In such circumstances there is a need for further research and experiments to learn more about the technological possibilities, about the disadvantages of particular solutions (and how they may be 
overcome), the economic costs and environmental gains of the technologies, and their acceptability to society. When using direct regulation, policy makers should give careful attention to the actual design of standards: their strictness, differentiation, timing, administration, flexibility and enforcement. The experiences in the US with innovation waivers and tradeable permits (described in Hahn, 1989) illustrate that the ways in which the instruments are designed and implemented are important determinants of the technological responses of industry. This is also the conclusion of Blazejczak, Edler, Hemmelskamp and Jänicke (1999) on the basis of German Studies. The authors developed a set of hypotheses about innovation-friendly environmental policy, having to do with aspects of instruments, policy styles and configurations of actors that are innovationfriendly. ${ }^{11}$

\section{Match making}

Another way of encouraging technological innovation is to build a network of technology suppliers, users, and research institutes, as in the Danish Clean Technology Development Programme. This programme not only provided firms with economic incentives for developing and implementing clean technologies, but, more importantly, provided them with informative incentives and necessary contacts for finding efficient technological solutions to specific environmental problems (Georg et al., 1992, pp.545-546). Of course, such a policy is not easy; it requires special competence on the part of policy makers. They must have a technological understanding of the production processes, the associated environmental problems and possible solutions if they are to act as a 'matchmaker' and identify the relevant participants for the development projects. They must also be careful to make sure that more radical solutions with potentially larger environmental benefits are developed and used.

\section{Technology compacts}

Technology compacts, described in Banks and Heaton (1995), are another way to promote technological innovation by setting an agenda of phased increments of technological change. As with covenants and negotiated rule making, there is the danger of strategic behaviour on the part of industry who may claim that it is impossible to develop technology that is both environmentally superior and economically feasible.

\section{Exploiting synergies between instruments}

From the discussion it should be clear that there is no single best instrument. Generally, policy instruments should be combined with one another to benefit from synergistic effects. A combination of standards with economic instruments is particularly useful by combining effectiveness with efficiency. A good example of an effective and economically efficient environmental policy are the US corporate automobile fuel economy (CAFE) standards which set progressive fuel economy targets for automobile

\footnotetext{
11 According to them innovation-friendly policy instruments should rely on the use of economic incentives, act in combination, be based on strategic planning and formulation of goals and support innovation as a process and take account of the different phases of innovation. Innovation-friendly policy styles are based on dialogue and consensus, are decisive, proactive and ambitious, open, flexible and knowledge-oriented. Innovation policy should include network management.
} 
manufacturers in the 1979-85 period under penalty of a fine of $\$ 50$ per car sold for each mile per gallon of shortfall. Tradeable pollution permits also deserve to be used more as they too combine effectiveness with efficiency. At this moment a nation-wide market exists for $\mathrm{SO}_{2}$ in the US where utilities can trade $\mathrm{SO}_{2}$ rights at the Chicago Board of Trade. Early results suggest that the tradeable permits for sulphur dioxide emissions will reduce the costs of the 1990 acid rain programme by 50 percent or more (Palmer et al., 1995).

\section{Modulating dynamics of sociotechnical change through public policy}

This section offers an alternative, non-instrument-based view on government policy for achieving environmental protection benefits, based on insights from technology dynamics studies, which sees technical change as a multi-actor and multi-level process. Within the alternative view, the starting point for policy and entrance point of government interventions is the capabilities, interests, interdependencies and interactions (games) of social actors around an environmental problem instead of the environmental problem itself and how this problem may be solved through the use of environmental policy instruments. In section 1 we saw that environmental policies being applied were not effective in securing goals (when goals were obtained it was usually through other developments). The policies were also found not to be efficient: the same results could have been achieved at lower costs, sometimes the costs exceeded the benefits from environmental protection, sometimes it was the other way-rarely do costs and benefits of government intervention equate at the margin. An explanation for this is that the instruments did not fit the economic-institutional context in which they were applied. This context consists of the problem holders (private and public companies engaged in environmentally disruptive activities, households), the actors who could supply a technical solution to the problem (capital good suppliers, government labs, consulting companies and other knowledge institutes, and the problem industry) and a range of other actors: environmental pressure groups, banks, insurance companies, users, scientist groups, and of course the government and politicians, each with their own interests, resources, views, assumptions and values. In this context the environmental problem is not given, but discussed and negotiated. Same with the solutions. Different actors favour different solutions. There is a continuing battle both over problem definitions and solutions, in an evolving sociotechnical landscape.

These battles are not a peripheral thing: they have an important influence on the choice and practical design of instruments (Hahn, 1989; Majone, 1976; Bressers and Huitema, 1996). According to Majone, the performance of policy instruments depends even more on the institutional framework in which they are used than on their technical characteristics. As he writes:

"The actual outcomes of environmental policies are affected more by the institutional arrangements emerging from the political process than by the technical characteristics of the instruments employed; to use a statistical image, the "within group' effects (the differential results obtained when the same tool operates under different institutional circumstances) dominate the 'between groups' effects (the results of different tools used under approximately equal conditions)", which leads him to the view that "the significant choice is not among abstractly considered 
policy instruments but among institutionally determined ways of operating them" (Majone, 1976, p.593).

Economists-more than any other profession-tend to find the influence of societal actors through politics on the choice and design of policy instruments a nuisance, as something which gets into the way of obtaining environmental benefits in an efficient way and elevating society to a higher level of wellbeing. But instead of deploring such societal interactions, such aspects should be taken into account. Policy should not be viewed as something which can occur outside society, especially not a democratic one. The government itself not only accommodates different interests but also houses them. This should not be assumed away. The modulation view first sketched in Rip and Kemp (1998) and further developed in Rip and Schot (1998) tries to offer a way out of this problem through its focus on societal interactions, and seeks to exploit interests in a way which benefits society at large. It says that government policy should be aimed not so much at achieving particular outcomes through the use of policy instruments but at modulating the dynamics of sociotechnical change, at making sure that the outcome of interactions-between firms and other actors in markets and policy arenas-lead to desirable outcomes. Within a modulation view, the different interests and problemsolving capabilities of actors, their agendas, expectations, ties and dependencies and the rules of the game (for example the way in which the policy making process is structured) are the entrance point of interventions.

The modulation views also says that the focus of environmental technology policy should be on all technologies. Any technology which uses less materials and energy is de facto an 'environmental technology', although some people may object to the use of this word. Such technologies should be an important target point of policy that tries to reconcile economic goals with environmental protection. It says that apart from changing frame conditions for technical change in an environment-friendly way there is a need for environmental policy to be explicitly-rather than implicitly-concerned with technical change. Here the main difference lies with economic views on environmental policy.

Key terms are alignment, network management, game management and process management; the overall concept is that of modulating technical change into environmentally beneficial directions. It says that government interventions should go beyond changing the cost and demand structure in which technical change occurs. Policies should be concerned with fostering linkages and establish a guide for environmental investment though for example the establishment of goals. This should be done in consultation with industry. Policies should take into account technical developments and utilise these for achieving environmental improvements. Sometimes this requires game management when industry is resistant to exploit certain possibilities because they have an interest in incumbent technologies.

The aim of game management is to create a situation in which there is a search for environment-friendly solutions and to select the best one. Here governments intervene in the competitive games between private companies and interactions between companies and social groups over problem definitions and appropriate solutions. This can be done in various ways: by changing the "rules of the games" or by changing the way in which the game is played. Examples of game management are: increasing the number of players 
(bringing in outsider firms with different interests and capabilities), prolong the game when no satisfactory results are likely to emerge, empower certain voices, and manipulate technological and economic expectations-for example, by securing a (future) market for a new product or by announcing that there will be a ban on a substances if scientific evidence tells that is dangerous. Game management seeks to exploit differences in economic interests by changing the stakes. It helps to go beyond win-win solutions within the existing economic framework. The power of markets is utilised by incorporating ecological concerns in the competitive process, for example by allowing only those products that are best from an ecological perspective. This helps to promote a search process for solutions, both by companies who are supplying an environmentally disruptive product and outsider firms operating in a different market. Game management creates winners and losers. In less conflict-ridden situations, government agencies could act not as a game manager but as a match maker by bringing together technology suppliers to work on a problem, promote learning and providing financial assistance. In the case of technological controversies, they could organise discussions between proponents and opponents, to generate better understanding of the issues at stake and guide technology developers in their decisions. Here they act as a mediator or moderator.

Apart from game management, network management and changing the economic frame conditions (through the use of taxes, covenants, standards, subsidies, etc.) there is also a need for policy to be oriented towards capacity building: to enhance the ability of companies to design environmentally improved products and their ability to adopt clean technologies. Lenox and Ehrenfeld (1997) speak about a company's 'environmental design capability': the ability to incorporate environmental concerns into product development. This capability depends on the integration of diverse knowledge resources through communicative linkages and on practical tools (such as design for the environment and green accounting) but also on the thought worlds or 'interpretive structures' of the actors. In their study on green product development they found that resources are insufficient if they are not linked with design teams and embedded in interpretive structures which value and understand the environmental information received (Lenox and Ehrenfeld, 1997, p.195). Environmental management systemswhich are compulsory for big environmentally intensive companies in the Netherlands - are a tool to achieve this, and were introduced precisely for this reason by Dutch authorities. Here we see that governments are already engaged in alignment policies, assuming a role as capacity builder and alignment agent.

The policies of alignment, capacity building and exploiting differences in economic interest through game management are not a substitute for the traditional policies. Within a modulation view, there is a need for corrective policies, either in the form of taxes, tradeable permits, environmental standards, fines and so on-policies hat change the frame conditions for economic behaviour and technical change. Such policies may be used to achieve set policy goals and limits and as part of a modulation approach in which the goals are not predetermined in a very specific way. The modulation approach thus does not preclude the use of traditional policies, it shows how policies may be used in a different way. It helps to identify useful points for intervention and exercise some leverage. It helps to fine-tune policy instruments to the context in which they are applied. 
This is important because in order for the policy interventions to have a decisive influence they must tip the balance of economic decision-making.

A modulation approach thus helps to see new entrance points for intervention for governments but also other actors (like NGOs) who want to further environmental goals. Changing the frame conditions through a pollution tax or regulation may not be sufficient for bringing about innovative responses. As expounded in structuralist-evolutionary approaches of technical change (Freeman, 1992; Nelson 1994; and Dosi, 1988) and as shown by virtually every management study, economic actors are not automata responding mechanically to changes in the cost and demand conditions. What an organisation and the people in it can do technologically is determined by what they have been doing in the past. Organisations have developed strategies and the people in them are equipped with an outlook on problems, certain capabilities and ways of doing which also acts as a shaping factor. At the same time, organisations are not altogether victims of the past. They have developed systems of intelligence for pursuing change and transformation. Companies, especially the multi billion ones with large capital assets in dynamic markets are forward-looking, they scan new technological developments and engage in the surveillance of market developments - the outcomes of which inform their research agenda and strategies. It is these things (the expectations, processes of anticipation, but also the capabilities and outlooks) that could be made an entrance point for government intervention, or at least an important consideration in the choice and design of government policy.

Examples of such entrance points for modulation policies are described in Schot and Rip (1998), Geels (1999) and Kemp et al. (2000). Important entrance points for interventions for governments (but also other actors) to further environmental goals through innovation are:

- Processes of anticipation and assessment (orientation towards the future) which might be improved. Actors do assessment all the time. They make assumptions about where their market is going. They scan possible technological futures and makes guesses about the impacts of changes in the sociotechnical landscape (such as the emergence of internet and public call for corporate responsibility) for their sector and company. Existing attempts of assessment might be broadened so as to include also environmental considerations. Discussions of sustainable futures and the development of sustainability images ("toekomstbeelden van duurzaamheid") are a way to bring in environmental concerns in processes of anticipation.

- Networks for learning and interaction which might be created with the help of government direct or indirectly through the funding of collaborative research.

- Promises-requirements cycles: to assist in the articulation of new technological possibilities, in the articulation of problems connected with their use and articulation of needs and wants; ways to do this is through technology experimentation and agenda building.

- Niches: spaces in which technologies are protected against selection pressures, acting as a learning environment and possible stepping stone for overall system change.

One tool to improve processes of anticipation and assessment and shape research agendas is the use of scenarios. Geels (1999) has described how the development of sociotechnical scenarios may contribute to processes of anticipation and alignment, and 
thus serve as vehicle for change. He identifies 3 purposes for which STSc may be used. A first purpose is that of promoting strategic thinking. STSc may help actors think more systematically about possible impacts of technologies and their role in the co-evolution of technology and society. Decisions and social interaction are informed by 'diffuse scenarios' (Rip and Schot, 1999). Actors are guided by assumptions about the role of humans, artefacts, organisations in future worlds. STS can be used to make the diffuse scenarios explicit and increase their quality.

A second purpose for which STSc could be used is to make 'road maps' and explore technological paths and technological 'forks', which then serve to inform public and private policy. STSc may be used to identify pathway technologies: technologies that allow you to move away from an existing technology regime to a new one. On the basis of their socio-technical scenarios about future transport systems, Elzen et al. (1998) identified light-weight electric vehicles as possible important stepping stones towards a more environmentally benign transport systems. These vehicles have a high innovationcascade potential, and allow for co-evolutionary learning, in which people's ideas of what a car should do may change.

The third purpose for which STSc may be used is to facilitate processes of mutual understanding between antagonistic actors. The framework on which STSc are built requires the participants to make their assumptions explicit, which is a precondition for mutual understanding. Differences in assumption and values may be unraveled through 'argumentive scenarios'. This has been done by Rip, Smit and van der Meulen (1994) on the issue of long-lived radioactive waste disposal. This also seems useful to do for biotechnology, a technology which is acclaimed to possess a significant potential for achieving environmental benefits.

The first two purposes have to do with orienting actors to the future and stimulating strategic thinking and thought experiments. The third with mediating conflicting views and interests.

Sociotechnical scenarios are referred by Geels to as "a tool for reflexive technology policy". They do not deliver 'silver bullet' solutions or offer ready-made advice in terms of what to do. The same is true for modulation policies. They offer a somewhat different perspective on governance which may be applied in an instrumental way, to achieve desirable outcomes.

An example of a modulation policy is strategic niche management. Strategic niche management (SNM) is a new approach, first suggested by Rip and further developed by Schot et al. (1994), Kemp et al. (1998) and Weber et al. (1999). SNM is aimed at modulating the dynamics of socio-technical change through the creation and management of spaces (niches) for the use of a new technology. In the spaces the technology is partly and temporarily protected from the normal selection pressures of business. ${ }^{12}$ The creation and management of niches is a way to work towards regime change.

12 The protection of innovations is not something unusual. Much innovations depend on research that is done within public laboratories or universities with the help of public money. In addition, companies themselves create a protected space for research by allowing researchers to do particular kinds of 
SNM involves the real use of technologies, in selected (protected) settings. The actual use of a new technology is important for articulation processes to take place, to learn about the viability of the new technology and build a network around the product whose semi-coordinated actions are necessary to bring about a substantial shift in interconnected technologies and practices. As we have argued, this is important in fostering regime shifts.

SNM is especially appropriate for so-called pathway technologies. Pathway technologies are technologies that (may) pave the way for new developments. They may also be called bridging technologies. They help to bridge the gap between the current regime (in which they may be used for certain purposes) and a new and more sustainable one. Pathway technologies are compatible with both the old and new regime and allow for a cascade of innovations. Energy storage is an example of a pathway technology: the storage of energy is important for the use of renewables but also useful within the centralised energy system as it may be used to deal with peak demand, helping to reduce peak loads. Electric propulsion and transport telematics (electronic information and reservation systems about transit) are examples of pathway technologies for public and intermodal transport. Both have been supported by public policies through special research programmes and there has been investment from industry in these technologies but there still is a gap between research and diffusion. A special type of support action is needed to bridge this gap. The Zero Emission Mandate of California which required that a certain percentage of new vehicles sold ( 2 per cent in 1998 and 10 per cent in 2003) are zero emission vehicles (at the point of use) is an attempt to cross this gap. It consisted of a forced introduction of zero emission vehicles in the market. It gave a big boost to the development of batteries, electric propulsion systems, quick recharging systems. It did not result in the wide use of BEVs but it forced automobile manufacturers to work on electric propulsion systems and to rethink car design. The attention to alternative fuel vehicles has resulted in the development of hybrid electric vehicles (in which batteries are combined with an internal combustion engine) and fuel cell vehicles. The latter will be introduced in the market in 2003, hybrid electric vehicles are already for sale.

The advantage of SNM is that is targeted to specific problems and needs connected with the use of new technologies and practices. User experiences are used to inform private investment and government support policies. By carefully choosing an appropriate domain of application the costs (of discomfort) may be kept low. Windows of opportunity are exploited at the local level while at the same time a transition path is created to a new and more sustainable system in a non-disruptive way. It helps actors to negotiate and explore various interpretations of the usefulness of specific technological options and the conditions of their application. Thus, SNM highlights choices and

research, to use office time, space and equipment. Sometimes an entirely new company unit is created in which a new product is developed free from the usual decision calculus. An example is the Smart car for which a technological niche is created through company subsidies, but with the hope that the car will become remunerative or that the knowledge obtained will pay off in some manner. Sometimes research in companies is kept secretly to the rest of the company because it may threaten positions within a company or for fear of failure. 
options and makes the introduction process more transparent and do-able for all parties involved including producers, users and policy-makers (Weber et al., 1998).

SNM has been attempted by companies for radical innovations such as optical fibres, cellular telephones, aspartame, and computer axial tomography (CT) scanners (Lynn et al., 1996), who used early markets as a stepping stone for penetrating mass markets. It is a new approach for policy makers although some government policies such as the ZEM in California and the Danish policy towards wind power could be labeled as de facto SNM policies.

Finally, it is to be noted that SNM is not a substitute for existing policies, but a useful addition, which is appropriate for working towards more sustainable technology systems. In doing so, SNM contributes to the goal of ecological restructuring. It is an example of an 'evolutionary' policy, aimed at deliberately creating path dependencies, and thus paths through circles of virtuous feedback through carefully targeted policy interventions, rather than at correcting perceived market failures. It helps to work towards system renewal instead of optimisation.

\section{Final remarks}

In this section I have put forward a strong argument for a modulation approach which attempts to steer processes of interaction rather than achieve particular outcomes, for example a particular reduction of pollutants. Examples of modulation policies are game management or the use of taxes. These policies fall into two categories: those that are explicitly concerned with processes of learning and innovation and those that are not. Taxes, subsidies, standards, covenants fall into the latter category. They have an important role to play in environmental policy. But there are limits to what can be achieved with such policies. In my opinion however they are unlikely to bring about an eco-restructuring. They may be used for achieving an 'environmental upgrading' of a sector or chain, what Elzen et al, (1996) call 'system optimisation'. They are less suited for achieving 'system renewal' or 'eco-transformation' which involves a replacement of existing trajectories by ones that are more environmental friendly. To achieve system renewal generic macropolicies are likely to be insufficient given the dominance of existing trajectories that have benefited from dynamic scale and learning economies and adaptation of the demand side and uncertainty about the alternatives. One has to appraise new trajectories and work towards them. This can be done through technology foresights and societal discussions and through experimentation at the local level with new technologies. Possible government policies to work towards system renewal are: the creation of spaces for learning about new technologies, the establishment of long term goals, and indicative, adaptive planning to guide private and public investment into new directions.

This requires a different type of approach for policy making, more participatory and more oriented towards experimentation, and the use of policies that are forward-looking, adaptive and reflexive. Suggestions as to actual policy interventions for promoting innovation, diffusion and system change into environment-enhancing directions can be found in Table 2 in the appendix. This table shows that there is no single policy that can do the job. All policies have a role to play, depending on the context in which and 
purpose for which they are applied. Designing environmental policies that promote innovation and dynamic efficiency (as opposed to the achievement of short term goals) is not an easy task. But this paper has suggested many practical policies how this may be done, using old and new entrance points for intervention.

\section{References}

Aggeri, Franck (1999), 'Environmental Policy and Innovation. A Knowledge-based Perspective on Cooperative Approaches', Research Policy 28: 699-717.

Arthur, W.B. (1988), 'Self-Reinforcing Mechanisms in Economics', in P. Anderson et al. (eds.), The Economy as an Evolving Complex System, Reading, MA: Addison-Wesley.

Aichholzer, Georg, and Gerd Schienstock (eds.), (1994), Technology Policy: Towards an Integration of Social and Ecological Concerns, Berlin: Walter de Gruyter.

Ashford, Nicholas A., George R. Heaton Jr., and W. Curtiss Priest, (1979), 'Environmental, Health, and Safety Regulation and Technological Innovation', in J.M. Utterback and C. Hill (eds.), Technological Innovation for a Dynamic Economy, 161-221.

Ashford, Nicholas, (1993), 'Understanding Technological Responses of Industrial Firms to Environmental Problems: Implications for Government Policy', in Kurt Fischer and Johan Schot (eds.), Environmental Strategies for Industry: International Perspectives on Research Needs and Policy Implications, Washington D.C.: Island Press.

Ashford, Nicholas A., Christine Ayers and Robert F. Stone, (1985), 'Using Regulation to Change the Market for Innovation', Harvard Environmental Law Review 9: 419-466.

Ayres, R.U. and U.E. Simonis (eds.) (1994). Industrial Metabolism. Tokyo: United Nations University Press.

Blazejczak, J., D. Edler, J. Hemmelskamp and M. Jänicke (1999) Environmental Policy and Innovation: An International Comparison of Policy Frameworks and Innovation Effects, will appear in P. Klemmer (ed.), Innovation Effects of Environmental Policy Instruments, Berlin: Analytica.

Bressers, J.Th.A, and D. Huitema (1996), Politics as usual. The effect of policy making on the design of economic policy instruments, CSTM, Enschede.

Deuten, J.J., A. Rip en W.A. Smit, 1998, Nieuwe werelden... Met micro-optica: Scenario's en scripts, en wat deze impliceren voor micro-optica onderzoek aan de Universiteit Twente (Enschede: Universiteit Twente)

Dosi, Giovanni (1982), 'Technological Paradigms and Technological trajectories: A Suggested Interpretation of the Determinants and Directions of Technical Change', Research Policy 6, 147-162.

Dosi, Giovanni (1988), 'The Nature of the Innovation Process', in Giovanni Dosi, Chris Freeman, Richard Nelson, Gerald Silverberg and Luc Soete (eds.) (1988), Technical Change and Economic Theory, London: Pinter Publishers.

Edquist, Charles (ed.) (1997), Systems of Innovation. Technologies, Institutions and Organizations, London and Washington: Pinter.

Elzen, Boelie, Remco Hoogma and Johan Schot (1996) Mobiliteit met toekomst. Naar een vraaggericht technologiebeleid, Ministerie van Verkeer en Waterstaat.

Elzen, B., Geels, F.W., Hoogma, R., Schot, J.W. and Te Velde, R., 1998, Strategieën voor innovatie: Experimenten met elektrische voertuigen als opstap naar marktontwikkeling, Report for the Dutch Electricity Utilities (Sep)

Faucheux, Sylvie (1999), Environmental Policy and Technological Change: Towards Deliberate Governance, paper for International Conference "Innovation-Oriented Environmental Regulation: Theoretical Approaches and Empirical Analysis", Potsdam, May 29-29, 1999.

Freeman, Chris, and Carlota Perez (1988), 'Structural Crises of Adjustment, Business Cycles and Investment Behaviour', in Giovanni Dosi, Chris Freeman, Richard Nelson, Gerald Silverberg 
and Luc Soete (eds.), Technical Change and Economic Theory, London: Pinter Publishers, 3866.

Freeman, Chris (1992), The Economics of Hope: Essays on Technical Change, Economic Growth and the Environment. London [etc.]: Pinter Publishers; New York: St. Martin's Press.

Geels, Frank, and Johan Schot (1998), Reflexive technology policies and sociotechnical scenarios, paper presented at Conference "Constructing tomorrow: technology strategies for the new millennium", 14-15 September 1998, Bristol, UK.

Geels, Frank (1999), Sociotechnical Scenarios as a Tool for Reflexive Technology Policies, paper for 4S Conference, 28-31 Oct, San Diego.

Hahn, Robert W., (1989), 'Economic Prescriptions for Environmental Problems: How the Patient followed the Doctor's Orders', Journal of Economic Perspectives, 3(2): 95-114.

Hartje, Volkmar J., (1985), Environmental Product Regulation and Innovation: Limiting Phosphates in Detergents in Germany, International Institute for Environment and Society (IIUG), IIUG dp 85-5, Wissenschaftszentrum Berlin.

Heaton Jr., George R., (1990), Regulation and Technological Change, paper for the WRI/OECDSymposium Toward 2000: Environment, Technology and the New Century, Annapolis, Maryland, June 13-15, 1990.

Hemmelskamp, Jens (1997), 'Environmental Policy Instruments and their Effects on Innovation', European Planning Studies, 5(2):177-193.

Kemp, René (1994), 'Technology and the Transition to Environmental Sustainability. The Problem of Technological Regime Shifts', Futures 26(10), 1023-46.

Kemp, René (1996), 'The Transition from Hydrocarbons. The Issues for Policy', in S. Faucheux, D. Pearce and J.L.R. Proops (eds.), Models of Sustainable Development, Cheltenham: Edward Elgar, 151-175.

Kemp, René (1997), Environmental Policy and Technical Change. A Comparison of the Technological Impact of Policy Instruments, Cheltenham: Edward Elgar.

Kemp, René, and Luc Soete (1992), 'The Greening of Technological Progress: An Evolutionary Perspective', Futures 24(5), 437-457.

Kemp, René, Ian Miles, Keith Smith et al. (1994), Technology and the Transition to Environmental Stability. Continuity and Change in Complex Technology Systems, final for SEER research program of the Commission of the European Communities (DG XII).

Kemp, René, Johan Schot and Remco Hoogma (1998), 'Regime Shifts to Sustainability through Processes of Niche Formation. The Approach of Strategic Niche Management', Technology Analysis and Strategic Management, 10(2): 175-195.

Kemp, René, Bernhard Truffer and Sylvia Harms (1998), 'Strategic Niche Management for Sustainable Mobility', in K. Rennings, O. Hohmeier, and R.L. Ottinger (eds.) (2000), Social Costs and Sustainable Mobility - Strategies and Experiences in Europe and the United States", Physica Verlag (Springer), Heidelberg, New York, 167-187.

Kemp, René, Keith Smith and Gerhard Becher (1999), How Should We Study the Relationship between Environmental Regulation and Innovation? Paper for International Conference "Innovation-Oriented Environmental Regulation: Theoretical Approaches and Empirical Analysis", Potsdam (Germany), May 27-29, 1999.

Kemp, René, and Andreas Reinstaller (1999), The creation of a technology path in a world of path dependence, paper for workshop "Path Dependence and Creation" in Maastricht, July 1-2, 1999.

Kemp, René, Arie Rip and Johan Schot (2000), Constructing Transition Paths through the Management of Niches, forthcoming in Raghu Garud and Peter Karnoe (eds.), Path Creation and Dependence, Lawrence Erlbaum Associates Publ..

Kooiman, Jan (ed.) (1993), Modern Governance. New Government-Society Interactions, London: Sage.

Lipsey, Richard G. and Kenneth Carlaw (1998), 'Technology Policies in Neo-Classical and Structrualist-Evolutionary Models'. STI Review 22: 31-73. 
Majone, Giandomenico (1976), 'Choice Among Policy Instruments for Pollution Control', Policy Analysis, 589-613.

Metcalfe, J.S. (1998), Evolutionary Economics and Creative Destruction, Routledge, London.

Metcalfe, J.S. and L.Georghiou (1998), 'Equilibrium and Evolutionary Foundations of Technology Policy'. STI Review 22: 75-100.

Mol, Arthur, (1995) The Refinement of Production. Ecological Modernisation Theory and the Chemical Industry, The Hague.

Molina, Alfonso H. (1993), 'In Search of Insights into the Generation of Techno-economic Trends: Micro- and Macro-constituencies in the Microprocessor Industry', Research Policy, 22, 473-506.

Nelson, Richard R., (1994), 'The Co-Evolution of Technology, Industrial Structure, and Supporting Institutions', Industrial and Corporate Change, 3(1): 47-63.

Nelson, Richard R., and Sidney G. Winter (1977), 'In Search of Useful Theory of Innovation', Research Policy 6, 36-76.

Nelson, Richard R., and Sidney G. Winter (1982), An Evolutionary Theory of Economic Change, Cambridge (Mass.): Bellknap Press.

Perez, Carlota (1983), 'Structural Change and Assimilation of New Technologies in the Economic and Social System', Futures, 15(4): 357-375.

Rennings, Klaus (1998), Towards a Theory and Policy of Eco-Innovation - Neoclassical and (Co-) Evolutionary Perspectives, Discussion Paper No. 98-24, Zentrum für Europäische Wirtschafts-forschung GmbH, Mannheim.

Rip, A, W.A. Smit, and B.J.R. van der Meulen, 1994, 'Radioactive waste disposal: Taking societal views into account', in: Environmental and ethical aspects of long-lived radioactive waste disposal, Nuclear Energy Agency and OECD.

Rip, Arie and René Kemp (1996), Towards a Theory of Socio-Technical Change, mimeo UT, report prepared for Batelle Pacific Northwest Laboratories, Washington, D.C. An edited version has been published as book chapter, 'Technological Change', in S. Rayner and E.L. Malone (1998), Human Choice and Climate Change. An International Assessment, Vol. 2, Batelle Press, Washington D.C., 327-399.

Rip, Arie, Tom Misa, and Johan Schot (eds.) (1995), Managing Technology in Society. New Forms for the Control of Technology, London: Pinter Publishers.

Rip, A., and J. Schot (1999): "Anticipation on Contextualization: Loci for Influencing the Dynamics of Technological Development", forthcoming in Sauer, D., and C. Lang (Hrsg.): Paradoxien der Innovation. Perspektiven sozialwissenschaftlichter Innovationsforschung, Frankfurt/New York, Campus Verlag, 1999. Proceedings, workshop Verbund sozialwissenschftliche Technikforschung, München, December 1998.

Rosenberg, Nathan (1976), 'The Direction of Technological Change: Inducement Mechanisms and Focussing Devices' in his book Perspectives on Technology, Cambridge: Cambridge University Press, 108-125.

Rosenberg, Nathan (1982), Inside the Black Box. Technology and Economics, Cambridge: Cambridge University Press.

Schot, Johan (1992), 'Constructive Technology Assessment and Technology Dynamics. The Case of Clean Technologies', Science, Technology and Human Values 17(1), 36-57.

Schot, Johan (1998), "The Usefulness of Evolutionary Models for Explaining Innovation. The Case of the Netherlands in the Nineteenth Century", History of Technology 14: 173-200.

Schmidtheiny, S., with the Business Council for Sustainable Development (1992), Changing Course: A Global Business Perspective on Development and the Environment, MIT Press, Cambridge, MA.

Weber, Matthias, Remco Hoogma, Ben Lane and Johan Schot, (1998) Experimenting with Sustainable transport Innovations. A Workbook for Strategic Niche Management, Seville/Enschede. 
Weber, Matthias,.and Andreas Dorda (1999), Strategic Niche Management: A Tool for the Market Introduction of New Transport Concepts and Technologies, IPTS Report, Febr 1999, 20-27.

Windrum, Paul (1999), Unlocking A Lock-In: Towards A Model Of Technological Succession, MERIT research memorandum 2/99-010, Maastricht. 


\section{Appendix}

Table 2 Suggestions about the use of policy instruments to promote the development and use of environmentally beneficial technologies in differing contexts

\begin{tabular}{|c|c|c|c|}
\hline Policy instrument & General inherent characteristics & $\begin{array}{l}\text { Purpose for which they } \\
\text { may be used }\end{array}$ & $\begin{array}{l}\text { Context in which they may be } \\
\text { applied }\end{array}$ \\
\hline $\begin{array}{l}\text { Technology-based envir- } \\
\text { onmental standards }\end{array}$ & $\begin{array}{l}\text { - effective in most cases (is when they are } \\
\text { adequately enforced) } \\
\text { - uniform standards give rise to inefficien- } \\
\text { cies in case of heterogeneous polluters }\end{array}$ & $\begin{array}{l}\text { technological diffusion } \\
\text { and incremental innova- } \\
\text { tion }\end{array}$ & $\begin{array}{l}\text { when differences in the marginal costs } \\
\text { of pollution abatement are small and } \\
\text { economically feasible solutions to en- } \\
\text { vironmental problems are available }\end{array}$ \\
\hline $\begin{array}{l}\text { Technology-forcing stan- } \\
\text { dards }\end{array}$ & $\begin{array}{l}\text { - effective (in focussing industry's minds on } \\
\text { environmental problem) } \\
\text { - danger of forcing industry to invest in } \\
\text { overly expensive and suboptimal tech- } \\
\text { nologies } \\
\text { - problem of credibility }\end{array}$ & technological innovation & $\begin{array}{l}\text { when technological opportunities are } \\
\text { available that can be developed at low } \\
\text { enough costs } \\
\text { when there is a consensus about the } \\
\text { appropriate compliance technology }\end{array}$ \\
\hline Innovation waivers & - same as technology-forcing standards & $\begin{array}{l}\text { technological } \\
\text { innovation }\end{array}$ & $\begin{array}{l}\text { when technological opportunities are } \\
\text { available and when there is uncertain- } \\
\text { ty about best solution }\end{array}$ \\
\hline Eco-taxes & $\begin{array}{l}\text { - efficient } \\
\text { - uncertainty about industry response } \\
\text { - danger that they provide a too weak and } \\
\text { indirect stimulus } \\
\text { - total environmental costs for industry are } \\
\text { - likely to be high } \\
\text { - limited political attractiveness }\end{array}$ & $\begin{array}{l}\text { For recycling and } \\
\text { material and energy } \\
\text { saving } \\
\text { technological diffusion } \\
\text { and incremental innova- } \\
\text { tion }\end{array}$ & $\begin{array}{l}\text { - in case of heterogeneous polluters that } \\
\text { respond to price signals } \\
\text { - when there are many different technol- } \\
\text { ogies for achieving environmental } \\
\text { benefits }\end{array}$ \\
\hline
\end{tabular}


Tradeable permits

Covenants and technology compacts

R\&D subsidies

Investment subsidies

Communication (e.g. ecolabels)

Network management
- $\quad$ effective

- cost effective (which means that environmental benefits are achieved at lowest cost)

- $\quad$ uncertainty about whether industry will meet agreements; should be sup-

plemented with penalty for non-complrance

- low administrative costs

- danger of funding second-rate projects

- danger of providing windfall gains to recipients

- in conflict with polluter-pays principle

- danger of windfall gains politically expedient

- helps to focus the attention of firms and consumers on environmental problems and available solutions to these problems

- little coercive power

- creates a platform for learning and interaction, to stimulate alignmen

technological diffusion and innovation technological diffusion

technological innovation

and diffusion

technological diffusion

technological innovation

echnological diffusion
- $\quad$ same as taxes

- costs of monitoring and transaction should not be prohibitively high

- $\quad$ in case of many polluters and many technological solutions

- when monitoring environmental performance is expensive

- when markets for environmental technology do not yet exist and when there is uncertainty about future policies

- when there are problems of appropriating the benefits from innovation

- when there are important knowledge spillovers

- $\quad$ in case of large social benefits and insufficient private benefits

- when industry suffers a competitive disadvantage due to less strict regulations in other countries

- when there is a lack of environmental consciousness

- when there are information failures 
coordinate interdependent activities solutions may be tailored to specific needs

- requires technological understanding of processes and products

Societal debates about environmental issues

Sustainability foresight studies

- Broadens processes of assessment

- Enhances strategic orientation

Setting of goals and use of indicative planning

- Provides clarity and (strategic) orientation

Game management

Strategic niche

management
For stimulating mutual understanding, learning about values and belief systems

Improving processes of anticipation

For learning about sustainability options (beyond eco-efficiency)

For altering fixed ideas and mind sets

For shaping business expectations and guiding strategic decisions

Radical innovations with significant sustainability benefits that do not offer a win-win solution

For learning about radical innovations and to stimulate processes of co-evolution
- Controversies about problems and solutions
- In case of oligopolies engaged in strategic behaviour over environmental issues

- For pathway technologies to a more sustainable system

- In case of attractive domains of application 